特集 800 号記念特集

順天堂医学. 2005, 51

P. $486 \sim 489$
『順天堂医学』の体裁・構成・出版社について

\author{
木 所 昭 夫* \\ AKIo KIDOKORO
}

700 号記念特集は昭和 55 年 12 月に発行された 26 巻 4 号で行われている.

以降, 25 年経過して, 51 卷 4 号で『順天堂医 学』は通刊 800 号を数えることになった。

701 号から 800 号までに至る 100 冊の表表紙に ついて,『体裁』『構成』がどのように変化した か, また, 出版社が学術社からキタ・メディアに 変わった事でどのように変化したかを見てゆき たい。

I . 表表紙の体裁の変化について

表表紙の体裁について，一見ではあまり变化が ないように見えるが, 細かく見ると, 100 冊が発 行される間に, かなり変化していることがわかった.

1. 701 号から 719 号までの変化について

27 巻 1 号 $(701$ 号 ) では『1981年 3 月』の位置 が, 700 号と異なり,太線から離れていたが, 28 巻 3 号 ( 707 号) では700号と同じ位置に戻って いた。

その後, 28 巻 4 号 ( 708 号) では701号と同じ 位置に戻るが， 30 巻 4 号（716号）では700号と 同じ位置に変化していた。この形は 31 巻 3 号 (719号)まで続いている.

昭和 54 年からの議事録を検討したが，この体 裁の変化がなぜ起きたのかについての記載がな く, 理由については不明である。

2. 720 号から 721 号までの変化

31 巻 4 号 ( 720 号) では, 目次が端から端まで に拡大し, 文字の大きさは 8 ポイントと大きく

*順天堂医学編集委員

順天堂大学医学部附属順天堂浦安病院外科教授

[Aug. 22, 2005 原稿受領〕
なった. 32 巻 1 号 ( 721 号) では, さらに目次の 文字の大きさが 10 ポイントと大きくなり，字体 も変わった. 字体についてキタメディアに確認し たところ， 20 年前， 31 巻が発行された当時は, コンピューターによる編集作業ではなく写植の時 代であったため, 現在で言う明朝体と呼ばれるも のと思われるとのことであった。

ただ，このポイントは現在のPC（マック・ ウィンドウズ) でのポイントであり，写植時代の 級数とは, 若干, 異なると思われる.

33 巻 4 号まで, 数字も巻, 号ともに 10 ポイン 卜のまま推移している.

\section{729 号からの変化}

月の印刷が無くなったこと, 年号の下段に和年 号が追加されたこと，○巻 ○号の文字が 20 ポイ ント, 巻と号が 16 ポイントと大きくなったこと, 年巻号の下に位置する線が細くなったこと，があ げられる。この変化について, 議事録には記載が なく, 変化の詳細は不明である.

4. 誤植について

39 巻 2 号は, 本来, 通刊 750 号であるべきとこ ろ, 749 号と印刷されており, 次号の 39 巻 3 号ま でも, 本来, 通刊751号であるべきところ, 通刊 747 号と印刷されていた。 39 巻 4 号は正確に通刊 752 号となっていた。その後，1年間に開催され た議事録に，誤植について検討されたとの記載は なかった。

5. 775 号からの変化

表表紙の目次から頁数, ガイドライン, 投稿規 程, 編集後記が消え, 中目次が登場した。

平成 11 年 9 月 30 日開催の第 367 回編集委員会 
議事録に,『45 巻 2 号（774号）の表紙に都民公 開講座の演者全員の名前と演題名が記載されてお らず, 演者に対して失礼だという意見が出て, 次 号から，本文に入る前に1頁の目次を入れる事に なり，その目次に，詳しい内容を入れることに なった』との記載があった。同年10月28日に開 催された 368 回編集委員会議事録には『表表紙に 大まかな目次のみを載せ, 次の1頁目に詳細な目 次を入れることになった』との記載があった。こ の後, 発行された 45 巻 3 号 (775号) からは, 編 集委員会の決定通り, 表表紙の目次には大まかな 内容が記載され, 中目次には, 頁数が入り, 表表 紙には記載できない詳しい演題名と演者名, ガイ ドライン, 投稿規程, 編集後記が掲載されていた. 表表紙から細かな頁数が消え，すっきりとした印 象になった。

\section{6. 表紙の紙質について}

46 巻 3 号 ( 779 号) 表紙の色調が『特厚ネズ ミ』から『雨面クロムカラーのネズミ（クロムの 質感)』に替わったが，46巻 4 号（780号）で元 の紙質『特厚ネズミ』に戻っている。この事情に ついては平成 12 年 9 月 14 日開催された第 376 回 編集委員会と平成 13 年 3 月 1 日に開催された第 380 回編集委員会の議事録に記載があった。編集 委員会宛, 湯浅晋治会員から, (1)表紙の色が全体 的に色あせた感じで, 少し, 暗い感じがすること, (2)表紙の紙質と色，活字の色が同系統でContrast が不明瞭であること. (3)目次の活字が小さすぎ表 紙の色とあわせて明暸ではないとの指摘があり， この対策として(1)表紙の質を一般雑誌のように艶 のある良質の紙にすること。(2)表紙の色を白か明 るい色にすること. (3)目次の活字を大きくするか, 濃くすることで, 表紙の装丁を一新して明るく attractiveにして欲しいとの提言があった。

第377回編集委員会で 2 種類の見本紙が (株) キタメディアから提供され, 検討された結果, 最 終的に 378 回編集委員会で『両面クロムカラーの ネズミ』紙の採用が了承され，2001年 2 月発行の 46 巻 3 号 $(779$ 号 ) では『特厚ネズミ』から『両 面クロムカラーのネズミ』紙に替わった.
第380回編集委員会では, 46 巻 3 号の表紙につ いての再検討が行われ，『両面クロムカラーのネ ズミ』紙では, 紙質的に污れが目立ちやすいとの 意見が多数でたため, 次号から以前と同じ『特 厚ネズミ』紙に戻った。

表紙の紙質の検討は,その後も継続して行われ， 47 巻 1 号から 4 号まで，それぞれ異なった紙質の ものが試験的に使われている.

最終的に 48 巻 1 号 $(785$ 号) から『特厚ネズミ にマットPP (つや消しフィルム) 処理を施した もの』に替わっており，印象としては柔らかく明 るく, 編集委員の先生方の間でも好評で, 現在ま で, 継続している.

\section{II . 構成の変化}

1. 概ね, 『順天堂医学』は特集一原著一症例報 告一報告一総説一研究会抄録一医学プロムナー ド一順天堂医学会総会資料・記録一てがみ一教 室業績一投稿規程-総目次索引一沿線別会員紹介 図一編集後記から構成されている。

2. 前付け：卯辞, 訃報, 集会案内について

訃報の掲載は平成 8 年 6 月発行の 42 巻 2 号 $(762$ 号）が最後であった。

平成 9 年 3 月発行の 43 巻 1 号 ( 765 号 ) の巻頭 言を最後に前付けは揭載されていない.

3. 特集について

各巻 2 号には退職教授記念講演が特集として組 まれている。

平成 5 年 4 月発行の 39 巻 1 号（749 号）から特 集として同空会主催の医学会の講演内容が掲載さ れ, 平成 14 年 3 月から【診療研究の最前線】, 平 成 17 年 3 月発行の 51 巻 1 号 (797号) から【医学 研究のUP-TO-DATE】という形に変化している.

平成 10 年 9 月発行の 44 巻 2 号 ( 771 号) から特 集【都民公開講座】の掲載が開始された。平成 10 年 12 月発行の 44 巻 4 号 ( 772 号) から特集【医師 会産業医研修会】の掲載が開始された。

\section{4. 総説}

平成 13 年 2 月発行の 46 巻 3 号 ( 779 号) から, 各巻 3 号は総説論文特集となっている. 総説論文 
特集号には，前項 3 の特集の掲載はない。

\section{5. 報告}

昭和 55 年 12 月発行の 26 巻 4 号 ( 700 号) では すでに揭載されており，ほとんど毎号で掲載され ている。 43 巻 3 号 ( 767 号) から成田医学教育 ワークショップと医学教育ミニワークショップの 報告が掲載されている.

6. 医学プロムナードについて

昭和 55 年 12 月発行の 26 巻 4 号 ( 700 号) で既 に掲載中であり，毎号全てに揭載されていた。

7. 医学会総会資料・記録

昭和 55 年 12 月発行の 26 巻 4 号 ( 700 号 ) で 既に, 掲載されており, その後も 43 巻 4 号 $(764$ 号 ）まで毎年 4 号に掲載されている。表表紙の目 次への記載はないが, 中の目次に記載されている.

\section{8. てがみ}

通常，特集の内容に対する会員読者からの質問 に答える形で，構成されている。708，720， 736, 738, 770, 777, 779, 780,781, 783, $785,786,787$ には揭載されていなかった。

\section{9. 教室業績}

昭和 55 年 12 月 26 巻 4 号 ( 700 号 ) では既に掲 載継続中であったが, 平成 4 年 12 月 38 巻 4 号 （748号）をもって，掲載が終了した。この中, 711 号には, 教室業績は掲載されていない. 教室 業績の掲載について, 昭和 55 年 6 月開催の 175 回, 同年 12 月開催の 180 回編集委員会で検討さ れたという記載があった。175回編集委員会議事 録に, 教室業績の掲載にはかなりの紙面が必要で あり，原稿が遅れる事が多く，整理や校正にも大 変な時間と労力が必要で, 教室業績の『順天堂医 学』への掲載は中止するか, 別冊とする方針とし たい旨, 書かれていた. 180 回編集委員会議事録 には, 教室業績記載要領を作成し, 是を守らない ものは掲載しない旨, 教授会で徹底を図る. 別冊 は作成せず，毎号に掲載するという内容が書かれ ていた。昭和 60 年 9 月開催の 232 回編集委員会議 事録には教室業績の頁数が多く, 問題となってい たようで, 削減のために学会発表は割愛する方針 で行くと書かれてあり, 同年 11 月に開催の 234
回編集委員会で学会発表とその他が昭和 60 年分 より割愛が決定されたとの記載があった。

10. 学位論文一覧

平成 9 年 3 月発行 43 巻 1 号 ( 765 号) から年 1 回まとめて掲載され, 現在は殆ど毎年 2 号に掲載 されている。

\section{1. 一般教育論文}

平成 11 年 3 月発行の 45 巻 1 号 ( 776 号 ) から揭 載が開始された。内容については，別項を参照し て頂きたい.

12. 投稿規程

平成 59 年 12 月発行の 30 巻 4 号 ( 716 号) から 掲載が開始され，平成 11 年 6 月発行の 45 巻 2 号 (774号) から中目次に移動した.

13. 投稿ガイドライン

平成 6 年 12 月発行の 40 巻 4 号 ( 756 号) から掲 載が開始され，757号から 761 号まで投稿規程の 後に掲載された。 762 号から以降は投稿規程の前 に掲載された。

775 号から表目次には揭載されず，中目次に掲 載されている.

14. 総目次索引

昭和 57 年 12 月発行の 28 巻 4 号 ( 708 号) から 掲載が開始され， 1 年間 1 回ずつ, 各巻 4 号に掲 載されている. 28 巻から 44 巻まで投稿ガイドラ インの前に掲載され，平成 11 年 12 月発行の 45 巻 4 号通巻 776 号で表目次から消え, 中目次に移行 した.

15. 沿線別会員紹介図

昭和 57 年 12 月発行の 28 巻 4 号 $(708$ 号 ) 平 成 3 年 3 月発行の 37 巻 1 号 ( 741 号) まで, 26 回 に渡って掲載された。平成 3 年 4 月に開催された 第283 回編集委員会記事録に,「会員紹介罒は741 号の埼玉県をもって, 全国を一巡したので, 最終 回とした」との記載があり,「今後の企画につい ては継続検討する」と記載されていた。

III. 出版会社の変遷

30 年間に渡り，学術社により印刷業務が行わ れていた。平成 8 年 12 月 19 日に開催された第 341 
回編集委員会で印刷業者の変更についての検討が 開始され，協議の結果，学術社を含めて，4社か ら，見積もりをとり，此較検討されることになっ たという記載が議事録にみられ，平成 9 年 1 月 30 日第 342 回編集委員会. 平成 9 年 2 月 27 日第 343 回編集委員会をへて, 43 巻 1 号の一般教育特集号 から (株) キタ・メディアに印刷会社を変更する ことが決定された。

しかし, 編集の都合で, 43 巻 1 号の一般教育特 集号より, 43 巻 2 号 ( 766 号) の方が早い発行と なったため, 実際は 43 巻 2 号から（株）キタ. メディアでの印刷が始まったと考えてよいと思わ れる.

文字について, 学術社とキタ・メディアでは若 干異なる印象があるが, 写植と PCによる変化か もしれない.

\section{おわりに}

主に表表紙の体裁について, 700号から800号 までどのような変遷があったか, について検討さ せて頂いた。

初めにも書いたが, 一見して, 何も変化がない ように思われたものが，1枚，1枚比較すること により,実に沢山の変化があることに気が付いた。 編集委員の先生方が, 知恵を絞って, 『順天堂医 学』をより良い方向にレベルアップしようとされ ているご努力の様子を垣間見ることが出来た。

『順天堂医学』もいよいよ800号の発行を迎えた。

このような素晴らしい歴史をもった『順天堂医 学』に感動し, 記念すべき『順天堂医学』800号の 編集に携わることが出来たことを感謝している.

今後 900 号に向かって『順天堂医学』がどのよ うな発展を見せてゆくか楽しみである。 